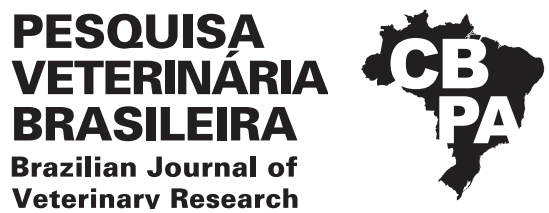

Pesq. Vet. Bras. 40(7):519-524, July 2020 DOI: $10.1590 / 1678-5150-P V B-6405$

Original Article

Veterinarv Research

ISSN 0100-736X (Print)

ISSN 1678-5150 (Online)

\title{
Quinolones resistance in Salmonella spp. isolated from broilers and chickens' carcasses under federal inspection ${ }^{1}$
}

\author{
Ana Luisa O.C. Carneiro ${ }^{2 *}$ (D), Rosiane L. Silva ${ }^{2}$, Isabela B.B.E. Rodrigues ${ }^{2}$, \\ Simone C. Machado ${ }^{3}$, Nathalie C. Cunha ${ }^{3}$, Elmiro R. Nascimento ${ }^{3}$, \\ Virginia L.A. Pereira ${ }^{2}$ and Dayse C.L. Abreu $^{2}$
}

\begin{abstract}
Carneiro A.L.O.C., Silva R.L., Rodrigues I.B.B.E., Machado S.C., Cunha N.C., Nascimento E.R., Pereira V.L.A. \& Abreu D.C.L. 2020. Quinolones resistance in Salmonella spp. isolated from broilers and chickens' carcasses under federal inspection. Pesquisa Veterinária Brasileira 40(7):519-524. Núcleo de Diagnóstico Avícola, Faculdade de Veterinária, Universidade Federal Fluminense, Rua Vital Brasil Filho 64, Niterói, RJ 24230-340, Brazil. E-mail: analuoccarneiro@gmail.com

We analyzed 77 Salmonella spp. strains, from which 20 were isolated from broilers (cloacal swabs) and 57 from chickens from slaughterhouses under federal inspection. The following serotypes were identified: Salmonella Saint Paul (29), Salmonella Heidelberg (27), Salmonella Anatum (9), Salmonella Cerro (5), Salmonella Senftenberg (5), Salmonella enterica (0:4,5) (1) and Salmonella enterica (0: 9.12) (1). Fifteen strains (19.5\%) were resistant to enrofloxacin, six $(7.8 \%)$ to ciprofloxacin, and $26(33.8 \%)$ to nalidixic acid in the Disk Diffusion Test. The fifteen enrofloxacin resistant strains were selected for the PCR to detect the genes gyrA, gyrB, $\operatorname{parC}$, and parE, and genetic sequencing to identify mutations in these genes. Five strains $(33.3 \%)$ had point mutations in the gyrA gene, and one $(6.7 \%)$ presented a point mutation in the parC gene. None of the 15 strains had mutations in the gyrB and parE genes, and none had more than one mutation in the gyrA gene or the other genes. The presence of point mutations in the strains studied corroborates with the phenotypic resistance observed to nalidixic acid. However, it did not explain the resistance to fluoroquinolones found in the 15 strains. Other mechanisms may be related to the fluoroquinolones resistance, highlighting the need for additional mutation screening.
\end{abstract}

INDEX TERMS: Quinolones, Salmonella spp., broilers, chicken carcass, fluoroquinolones, antimicrobial resistance.

RESUMO.- [Resistência à quinolonas em Salmonella spp. isoladas de frangos vivos e carcaças sob inspeção federal.] Foram analisadas neste estudo 77 estirpes de Salmonella spp., 20 isoladas de frangos vivos (suabes de cloaca) e 57 isoladas de carcaças, provenientes de abatedouros frigoríficos sob Inspeção Federal. Foram identificados os seguintes sorotipos: Salmonella Saint Paul (29), Salmonella Heidelberg (27), Salmonella Anatum (9), SalmonellaC erro (5), Salmonella Senftenberg (5),

\footnotetext{
${ }^{1}$ Received on September 20, 2019.

Accepted for publication on January 18, 2020.

${ }^{2}$ Graduate Program in Veterinary Hygiene and Technological Processing of Products of Animal Origin, Faculdade de Veterinária, Universidade Federal Fluminense (UFF), Rua Vital Brasil Filho 64, Niterói, RJ 24230-340, Brazil. *Corresponding author: analuoccarneiro@gmail.com

${ }^{3}$ Núcleo de Diagnóstico Avícola, Faculdade de Veterinária, Universidade Federal Fluminense, Rua Vital Brasil Filho 64, Niterói, RJ 24230-340, Brazil.
}

Salmonella enterica (0: 4,5) (1) e Salmonella enterica $(0: 9,12)$ (1). Do total de estirpes estudadas, $15(19,5 \%)$ se mostraram resistentes à enrofloxacina, seis $(7,8 \%)$ à ciprofloxacina e 26 $(33,8 \%)$ ao ácido nalidíxico no Teste de Difusão em Disco. Foram selecionadas as 15 estirpes resistentes à enrofloxacina para a realização da PCR para detecção dos genes gyrA, gyrB, parC e parEe para sequenciamento genético do produto da PCR para identificação de mutações nesses genes. Cinco estirpes $(33,3 \%)$ apresentaram mutações pontuais no gene gyrA e uma $(6,7 \%)$ apresentou mutação pontual no gene parC. Nenhuma das 15 estirpes apresentou mutações nos genes gyrB e parE e nenhuma apresentou mais de uma mutação no gene gyrA ou nos outros genes. A existência apenas de mutações pontuais em alguns genes das estirpes analisadas está de acordo com a resistência fenotípica observada ao ácido nalidíxico, mas não explica a resistência às fluoroquinolonas encontrada nas 
15 estirpes. Outros mecanismos de resistência podem estar relacionados à resistência encontrada às fluoroquinolonas e estudos adicionais são necessários para investigar sua presença.

TERMOS DE INDEXAÇÃO: Quinolonas, Salmonella spp., frangos vivos, carcaças de frango, fluoroquinolonas, resistência antimicrobiana.

\section{INTRODUCTION}

Bacteria of the genus Salmonella are essential pathogens for causing diseases in animals and man, and are considered of great significance for both public and animal health.

Some serotypes, known as paratypical, may not cause clinical disease in birds. However, most of them can multiply and remain in their digestive tract for some time, spreading in the farm environment. By contaminating poultry origin products to human consumption, they may be responsible for human outbreaks of food infection (Berchieri Jr. \& Freitas Neto 2009, Andreatti Filho 2009, Gast 2013). The paratypical serotypes most commonly described in poultry environments, birds and their products, are the serotypes Enteritidis, Albany, Heidelberg, Mbandaka and Newport (Brasil 2008, Dutil et al. 2010, FDA 2012, Robinson 2013, Cardoso et al. 2015, Pandini et al. 2015, PHAC 2017).

Salmonella infection leads to different clinical signs in humans, with gastrointestinal infection being the most common and generally self-limiting manifestation (Rezende et al. 2016, Draper et al. 2017).

Another important fact related to Salmonella spp. is the constant description of resistance to various antimicrobials, such as those of the quinolone class (Duarte et al. 2009, Mion et al. 2014, Casas et al. 2016, Neves et al. 2016, Rodrigues et al. 2017). Resistance in Salmonella spp. quinolones have been recorded in countries such as China, Hong Kong, Italy, the United Kingdom and Brazil (Eaves et al. 2004, Duarte et al. 2009, Lai et al. 2014, Lin et al. 2015,García-Fernández et al. 2015, Casas et al. 2016). Some countries showed a significant increase in resistance, such as China, which observed an increase from $4.4 \%$ to $41.5 \%$ of ciprofloxacin resistance, from 2009 to 2012 (Lai et al. 2014). Several studies have linked the therapeutic and prophylactic use of quinolones in animals with the emergence and spread of resistance from these pathogens (Yan et al. 2011, Cheng et al. 2012, Finley et al. 2013).

Quinolones, antimicrobials with a full application for the treatment of diseases in both humans and animals, were developed to identify nalidixic acid in the 1960s. In the 1980s, fluoroquinolones were developed and considered second-generation quinolones, with a spectrum of action on Gram-negative and Gram-positive bacteria. Enrofloxacin, a fluoroquinolone developed exclusively for use in animals, has broad antibacterial activity and is commonly used in Brazil's poultry production. Ciprofloxacin, in addition to its use in poultry production, is also used to treat human salmonellosis (Ito et al. 2005, Górniak 2011).

Salmonella spp. may develop chromosome and plasmid resistance to quinolones. Chromosome-mediated resistance can cause overexpression of efflux pumps or changes in porins present in the outer bacterial membrane, reducing the accumulation of antimicrobials in the bacteria. Another mechanism mediated by chromosomes is the conformational alteration of enzymes responsible for the replication of bacterial
DNA (García-Fernández et al. 2015). This type of mutation is the most frequent in Salmonella (Sinwat et al. 2018). It occurs by specific mutations that result in amino acid substitutions in the coded enzymes DNA Gyrase and Topoisomerase IV in the subunits encoded by the gyrA, gyrB, parC, or parE genes. These enzymes are involved in the bacterial DNA replication process, which is essential for bacterial survival. Mutations in $g y r A, \operatorname{gyr} B, \operatorname{parC}$, or parE in the regions that are part of the quinolone binding site are called Quinolone Resistance Determining Region (QRDR). The mutations alter these enzymes' structure, preventing quinolones from becoming connected to this site, reducing bacterial susceptibility to quinolones (Gouvêa et al. 2015, Thong et al. 2015, Sinwat et al. 2018). In Salmonella spp. mutations in gyrA are the most frequent, which can be explained due to the positioning of the enzyme DNA Gyrase in the bacterial DNA replication fork, which makes the inhibitory action of quinolone more effective than the enzyme Topoisomerase IV. Consequently, this may have created a selective pressure that caused the DNA Gyrase genes, especially the gyrA gene, to mutate more frequently to avoid quinolones' inhibitory action (Thong et al. 2015). Mutations in the $\operatorname{parC}$ gene for Topoisomerases IV occur less frequently, and mutations in the gyrB and parE genes have been considered rare in Salmonella (Kim et al. 2011, Yang et al. 2012, Thong et al. 2015, Lin et al. 2015).

Although antimicrobials are not indicated in most cases of salmonellosis in humans, its use becomes necessary in severe cases of systemic infections (Boxstael et al. 2012, WHO 2018). However, the antimicrobials' lack of susceptibility increases the risk of treatment failures (Park et al. 2019).

This study aimed to verify resistance to quinolones, enrofloxacin, ciprofloxacin, and nalidixic acid by mutating the genes gyrA, gyrB, parC and parE in strains of Salmonella spp., isolated from live chickens and carcasses from slaughterhouses with Federal Inspection Service.

\section{MATERIALS AND METHODS}

Obtaining strains of Salmonella spp. In this study, we used 77 strains of Salmonella spp., 20 of which were isolated from live chickens (cloaca swabs), and 57 from carcasses from slaughterhouses under federal inspection. The samples were sent to the "Laboratório de SanidadeAvícola", "Faculdade de Veterinária", of the "Universidade Federal Fluminense" (UFF), included in nutrient Agar (VWR Chemicals).

Strains serotyping. The strains were reactivated in Brain Heart Infusion (BHI) broth, included in nutrient Agar and sent to the "Laboratório de Enterobactérias" of the "Instituto Oswaldo Cruz" /"FundaçãoInstituto Oswaldo Cruz" (Fiocruz) for serotyping.

Antimicrobial susceptibility test. The 77 strains studied were subjected to the Disc-Diffusion test (CLSI 2018) to verify resistance to nalidixic acid, ciprofloxacin, and enrofloxacin.

Polymerase chain reaction (PCR) of the gyrA, gyrB, parC, and parE genes. PCR was performed at the "Laboratório de Epidemiologia Molecular" of UFF. For the extraction of bacterial DNA, strains of Salmonella spp. resistant to enrofloxacin by the Disc-Diffusion test were reactivated in $\mathrm{BHI}$ broth and subjected to the thermal method (AndreattiFilho et al. 2011). To detect chromosomal mutations in the DNA Gyrase and Topoisomerase IV enzymes of the strains of Salmonella spp., The gyrA, gyrB, parC, and parE genes were amplified by PCR, in a thermocycler (Thermo Electron Corporation), according to Kim et al. (2011). Primers were used to amplify the quinolone resistance region (Quinolone Resistance Determining Region - QRDR) 
in the $\operatorname{gyr} A, \operatorname{gyr} B, \operatorname{parC}$, and parE genes, producing fragments of 610 , 660, 950 and 897 base pairs (bp), respectively (Table 1).

Purification, preparation, and genetic sequencing of samples. The samples were purified using the GFX ${ }^{\mathrm{TM}}$ PCR DNA and Gel Band Purification Kit according to the manufacturer's instructions and subsequently sent to Subunit RPT01A - DNA Sequencing, RJ from Fiocruz and sequenced in the DNA sequencer ABI 3730 (AppliedBiosystems/USA).

Detection of mutation in QRDR. The files containing the nucleotide sequences of the quinolone resistance region of the gyrA, gyrB, parC, and parE genes of the Salmonella spp. Samples were read in the BioEdit program (BioEdit Sequence Alignment Editor) to check the sequences' quality and generate new files in the "Fasta" format. All sequences obtained were compared with those of GenBank using the Blast algorithm ${ }^{4}$.For the detection of chromosomal mutations in the QRDR region of the gyrA, gyrB, parC, and parE genes, the files in "Fasta" format were read by the ResFinder program available on the Center for Genomic Epidemiology website ${ }^{5}$, according to Zankari et al. (2012).

\section{RESULTS}

The most frequent serotypes of Salmonella enterica were Saint Paul (29/77,37.7\%), Heidelberg (27/77,35.1\%) and Anatum $(9 / 77,11.7 \%)$. Cerro and Senftenberg had a frequency of $6.5 \%$ (5/77), and serotypes 0: 4.5 and 0: 9.12 had a frequency of $1.3 \%(1 / 77)$.

After undergoing the Disc-Diffusion test, for the evaluation of resistance to the antimicrobials enrofloxacin, ciprofloxacin and nalidixic acid, 19.5\% (15/77) of the strains showed resistance to enrofloxacin, $7.8 \%(6 / 77)$ ciprofloxacin and $33.8 \%$ (26/77) to nalidixic acid (Table 2).

The Heidelberg serotypes, 0: 4.5 and 0: 9.12, were resistant to the three antimicrobials tested. Of these, the Heidelberg serotype showed the highest frequency of resistance to enrofloxacin $(11 / 15,73.3 \%)$, Ciprofloxacin $(4 / 6,66.7 \%)$ and nalidixic acid $(20 / 26,76.9 \%)$. The Senftenberg serotype did not show resistance to any of the three antimicrobials tested. The complete result of the resistance profile is shown in Table 2.

Of the 15 strains resistant to enrofloxacin, five (33.3\%) had mutations in the gyrA gene. These mutations were isolated. The five mutations found occurred at codon 83, leading to a change from the amino acid Serine to Phenylalanine (TCC $\rightarrow$ TTC). One of the 15 strains $(6.7 \%)$ showed a mutation in the parC gene. The mutation found occurred at codon 84, leading to a change from the amino acid Glutamic Acid to Lysine (GAA $\rightarrow$ AAG). None of the 15 strains had mutations in the gyrB and parE genes or more than one mutation in the gyrA gene or the other genes (Table 3 ).

\section{DISCUSSION}

The Salmonella serotypes identified in this study may cause mild gastrointestinal diseases (Rezende et al. 2016, Draper et al. 2017) to more severe extraintestinalconditions, as verified by the Heidelberg serotype, responsible for cases of septicemia, myocarditis, and death (Dutil et al. 2010). This fact makes production birds and their derived products essential

\footnotetext{
${ }^{4}$ Available at $<$ available at https://blast.ncbi.nlm.nih.gov/Blast.cgi>

5 Available at $<\mathrm{http}: / /$ www.genomicepidemiology.org/>
}

vehicles for the dissemination of this agent. The Heidelberg serotype was one of the most isolated in this study and in the work of Pandini et al. (2015). They detected Salmonella Heidelberg in $12.82 \%$ of isolates from swine trawlers from broiler farms in the state of Paraná. These same authors detected serotypes different from those isolated in this study, such as the Mbandaka and Newport serotypes, with frequencies of $10.25 \%$ and $S$. Schwarzengrund, $S$. Enteritidis, $S$. Livingstone, and $S$. Orion, with $7.70 \%$ frequency each. Cardoso et al. (2015) also detected serotypes different from those isolated in this study in chicken carcasses from slaughterhouses in the state of São Paulo/SP and the most frequent serotype was Enteritidis (49.4\%) followed by $S$. Albany serotypes (15.7\%), S.Infantiles (11.2\%), S. Agona (5.6\%), S. Tennessee (4.5\%), Salmonella spp. (3.4\%), S. Kentucky (2.3\%), S. Montevideo (1.1\%), and $S$. Newport (1.1\%). The Heidelberg and 0: 4.5 serotypes, also isolated in the present study, were the least frequent, with an isolation frequency of $3.4 \%$ and $2.3 \%$, respectively. The serotype most frequently isolated in this study was Saint Paul. In 2014, this serotype was the third most reported in Australia, accounting for 11\% of all salmonellosis reports in this country (Draper et al. 2017).

Salmonella resistance to quinolones has been detected worldwide (Eaves et al. 2004, Lai et al. 2014, Lin et al. 2015, García-Fernández et al. 2015). In a study carried out in Recife, Brazil, Duarte et al. (2009) analyzed the susceptibility to antimicrobials of 19 strains of Salmonella spp., isolated from chicken carcasses. They found a percentage of $5.2 \%$ resistance for the three quinolones tested (enrofloxacin, ciprofloxacin, and norfloxacin). Another study, carried out in São Paulo, detected 16 strains resistant (17.5\%) to ciprofloxacin in 91 strains of Salmonella spp. (Casas et al. 2016). These percentages were like those found in this study. The presence of Salmonella strains resistant to quinolones in foods, especially those used for treatment in humans, such as nalidixic acid and ciprofloxacin, is worrying because when its use becomes necessary for the treatment of serious infections it can increase the risk of failure (Park et al. 2019).

The existence of point mutations in some genes of the strains analyzed corroborates with the phenotypic resistance observed to nalidixic acid. However, it does not explain the resistance to fluoroquinolones found in the 15 strains. In this study, we only found point mutations in $\operatorname{gyr} A$, and $\operatorname{parC}$ and, therefore, resistance to fluoroquinolones in strains of Salmonella detected by the phenotypic test may be due to other resistance mechanisms than the mutation in the

Table 1. Primers, nucleotide sequences and size of amplicons used for PCR amplification of thegyrA, gyrB, parC and parE genes in strains of Salmonella spp.

\begin{tabular}{lcc}
\hline Primer & Sequence (5' to 3') & pb \\
\hline gyrA $-F$ & CGA GAG AAA TTA CAC CGG TCA & 610 \\
gyrA $-R$ & AGC CCT TCA ATG CTG ATG TC & \\
gyrB $-F$ & CTG CTT TAC CAA CAA CAT TCC & 660 \\
gyrB $-R$ & TTG TCC GGG TTG TAC TCG TC & \\
$\operatorname{parC}-F$ & ATG AGC GAT ATG GCA GAG C & \\
$\operatorname{parC}-R$ & GCG AAC AGA TGG TTC ATC AC & 950 \\
$\operatorname{parE}-F$ & GCG GAA GAT ATC TGG GAT CG & \\
$\operatorname{parE}-R$ & CAG CAG CAT ATC CAT CAT CG & 897
\end{tabular}


Table 2. Frequency of isolation and resistance assessment against the antimicrobials enrofloxacin, ciprofloxacin and nalidixic acid in strains of Salmonella spp. $(n=77)$ isolated from live chickens and carcasses in slaughterhouses with Federal Inspection Service

\begin{tabular}{|c|c|c|c|c|c|c|c|c|}
\hline \multirow{3}{*}{$\begin{array}{l}\text { Serotype } \\
\text { Saint Paul }\end{array}$} & \multirow{2}{*}{\multicolumn{2}{|c|}{ Frequency (\%) }} & \multicolumn{6}{|c|}{ Resistance } \\
\hline & & & \multicolumn{2}{|c|}{ Enrofloxacin (\%) } & \multicolumn{2}{|c|}{ Ciprofloxacin (\%) } & \multicolumn{2}{|c|}{ Nalidixic acid (\%) } \\
\hline & 29 & 37.7 & 1 & 6.7 & 0 & 0.0 & 2 & 7.7 \\
\hline Anatum & 9 & 11.7 & 0 & 0.0 & 0 & 0.0 & 1 & 3.8 \\
\hline Cerro & 5 & 6.5 & 1 & 6.7 & 0 & 0.0 & 1 & 3.8 \\
\hline 0: 9.12 & 1 & 1.3 & 1 & 6.7 & 1 & 16.7 & 1 & 3.8 \\
\hline Senftenberg & 5 & 6.5 & 0 & 0.0 & 0 & 0.0 & 0 & 0.0 \\
\hline \multirow[t]{2}{*}{ Total } & 77 & 100.0 & 15 & 100.0 & 6 & 100.0 & 26 & 100.0 \\
\hline & $100 \%$ & & $19.5 \%$ & & $7.8 \%$ & & $33.8 \%$ & \\
\hline
\end{tabular}

Table 3. Mutations in the gyrA, gyrB, parC and parE genes found in the 15 strains of Salmonella spp. resistant to enrofloxacin, ciprofloxacin and nalidixic acid

\begin{tabular}{|c|c|c|c|c|c|c|}
\hline \multirow{2}{*}{ Serotype } & \multicolumn{3}{|c|}{ Phenotypic susceptibility } & \multirow{2}{*}{ Mutation in (position) } & \multirow{2}{*}{ Nucleotide change } & \multirow{2}{*}{ Amino Acid change } \\
\hline & ENO & CIP & NAL. AC. & & & \\
\hline Saint Paul & $\mathrm{R}$ & I & $\mathrm{R}$ & - & - & - \\
\hline Heidelberg & $\mathrm{R}$ & I & $\mathrm{R}$ & $\operatorname{gyr} A(\mathrm{~S} 83 \mathrm{~F})$ & TCC to TTC & Serine to Phenylalanine \\
\hline Heidelberg & $\mathrm{R}$ & I & $\mathrm{R}$ & - & - & - \\
\hline Heidelberg & $\mathrm{R}$ & $\mathrm{R}$ & I & gyra (S83F) & TCC to TTC & Serine to Phenylalanine \\
\hline Heidelberg & $\mathrm{R}$ & I & $\mathrm{R}$ & - & - & - \\
\hline Heidelberg & $\mathrm{R}$ & I & $\mathrm{R}$ & - & - & - \\
\hline Heidelberg & $\mathrm{R}$ & I & $\mathrm{R}$ & $\operatorname{gyr}(\mathrm{S} 83 \mathrm{~F})$ & TCC to TTC & Serine to Phenylalanine \\
\hline Heidelberg & $\mathrm{R}$ & I & $\mathrm{R}$ & - & - & - \\
\hline Heidelberg & $\mathrm{R}$ & $\mathrm{R}$ & $\mathrm{R}$ & $\operatorname{parC}(\mathrm{E} 84 \mathrm{~K})$ & GAA to AAG & Glutamic acid to Lysine \\
\hline Heidelberg & $\mathrm{R}$ & $\mathrm{R}$ & $\mathrm{R}$ & $\operatorname{gyr} A(\mathrm{~S} 83 \mathrm{~F})$ & TCC to TTC & Serine to Phenylalanine \\
\hline Heidelberg & $\mathrm{R}$ & $\mathrm{R}$ & $\mathrm{R}$ & - & - & - \\
\hline Heidelberg & $\mathrm{R}$ & I & $\mathrm{R}$ & - & - & - \\
\hline Cerro & $\mathrm{R}$ & I & $\mathrm{R}$ & - & - & - \\
\hline 0: 9.12 & $\mathrm{R}$ & $\mathrm{R}$ & $\mathrm{R}$ & - & - & - \\
\hline $0: 4.5$ & $\mathrm{R}$ & $\mathrm{R}$ & $\mathrm{R}$ & $\operatorname{gyr} A(\mathrm{~S} 83 \mathrm{~F})$ & TCC to TTC & Serine to Phenylalanine \\
\hline
\end{tabular}

ENO = Enrofloxacin, CIP = ciprofloxacin, NAL. AC. = nalidixic acid, $\mathrm{R}=$ resistant, $\mathrm{I}=$ intermediate.

studied genes. The quinolones' targets are the enzymes DNA Gyrase and Topoisomerase IV, which subunits are encoded by the genes gyrA and gyrB (DNA Gyrase) and parC and parE (Topoisomerase IV). One of the main resistance mechanisms developed by Salmonella is the mutation in these genes, preventing the binding of the antimicrobial molecule to enzymes and thereby ensuring the survival of these bacteria (Thong et al. 2015, Sinwat et al., 2018). Point mutations in the $\operatorname{gyr} A, \operatorname{gyr} B, \operatorname{par} C$, or parE genes lead to resistance to first-generation quinolones. Resistance to fluoroquinolones in Enterobacteriaceae generally results from two or more mutations in the quinolone resistance genes determining region of DNA Gyrase and Topoisomerase IV (Thong et al. 2015 \& Campioni et al. 2017).

\section{CONCLUSIONS}

Saint Paul and Heidelberg's serotypes were the most frequently identified in this study. The Heidelberg serotype was the one with the highest percentage of resistance to enrofloxacin, ciprofloxacin, and nalidixic acid.

The presence of point mutations in the gyrA and parC genes was predominant in strains of Salmonella spp. isolated from live chickens and carcasses but did not explain the phenotype of these strains' resistance to the antimicrobials enrofloxacin and ciprofloxacin.

The presence of strains resistant to these antimicrobials in birds and their products is worrying, and the results obtained indicated the presence of other resistance mechanisms that should be investigated.

Conflict of interest statement.- There are no conflicts of interest. 


\section{REFERENCES}

Andreatti Filho R.L. 2009. Paratifo aviário, p.18-33. In: Revolledo L. \& Ferreira A.J.P. (Eds), Patologia Aviária. Manole, Barueri.

Andreatti Filho R.L., Gonçalves G.A.M., Okamoto A.S. \& Lima E.T. 2011. Comparação de métodos para extração de DNA na reação em cadeia da polimerase para detecção de SalmonellaentericasorovarEnteritidis em produtos avícolas. Ciênc. Anim. Bras. 12(1):115-119. <http://dx.doi. org/10.5216/cab.v12i1.3774>

Berchieri Jr A. \& Freitas Neto O.C. 2009. Salmoneloses. p.631-648. In: Berchieri Jr A., Silva E.N., Di Fábio J., Sesti L. \& Zuanaze M.A.F. (Eds), Doenças das Aves. $2^{\underline{a}}$ ed. Fundação APINCO de Ciência e Tecnologia Avícolas, Campinas.

Boxstael S.V., Dierick K., Van Huffel X., Uyttendaele M., Berkvens D., Herman L., Bertrand S., Wildemauwe C., Catry B., Butaye P. \& Imberechts H. 2012. Comparison of antimicrobial resistance patterns and phage types of Salmonella Typhimurium isolated from pigs, pork in Belgium between 2001 and 2006. Food Res. Int. 45(2):913-918. <http://dx.doi.org/10.1016/j. foodres.2011.05.025>

Brasil 2008. Programa Nacional de Monitoramento da Prevalência e da Resistência Bacteriana em Frangos: relatório do monitoramento da prevalência e do perfil de suscetibilidade aos antimicrobianos em enterococos e salmonelas isolados de carcaças de frangos congeladas comercializadas no Brasil. Agência Nacional de Vigilância Sanitária (ANVISA), Brasília. 188p.

Campioni F., Souza, R.A., Martins V.V., Stehling E.G., Bergamini A.M.M. \& Falcão J.P. 2017. Prevalence of gyrA mutations in nalidixic acid-resistant strains of SalmonellaEnteritidis isolated from humans, food, chickens, and the farm environment in Brazil. Microbial Drug Resistance 23(4):421-428. <http://dx.doi.org/10.1089/mdr.2016.0024> <PMid:27559761>

Cardoso A.L.S.P., Kanashiro A.M., Stoppa G.F.Z., Castro A.G.M., Luciano, R.L. \& Tessari E.N.C. 2015. Ocorrência de Salmonella spp. em carcaças de frango provenientes de abatedouros do estado de São Paulo, Brasil, no período de 2000 a 2010. Revta Cient. Med. Vet. 13(1).

Casas M.R.T., Camargo C.H., Soares F.B., Silveira W.D. \& Fernandes S.A. 2016. Presence of plasmid-mediated quinolone resistance determinants and mutations in gyrase and topoisomerase in Salmonella enterica isolates with resistance and reduced susceptibility to ciprofloxacin. Diagn. Microbiol. Infect. Dis. 85(1):85-89. <http://dx.doi.org/10.1016/j.diagmicrobio.2016.01.016> $<$ PMid:26971183>

Cheng A.C., Turnidge J., Collignon P., Looke D., Barton M. \& Gottlieb T. 2012. Control of Fluoroquinolone Resistance through Successful Regulation, Austrália. Emerg. Infect. Dis. 18(9):1453-1460.<http://dx.doi.org/10.3201/ eid1809.111515> <PMid:22932272>

CLSI 2018. Performance Standards for Antimicrobial Susceptibility Testing. 28th ed. CLSI supplement M100, Clinical and Laboratory Standard Institute, Pennsylvania.

Draper A.D.K., Morton C.N., Heath J.N.I., Lim J.A. \& Markey P.G. 2017. An outbreak of SalmonellaSaintpaul gastroenteritis after attending a school camp in the Northern Territory, Australia. Commun. Dis. Intell. Q. Rep. 41(1):E10-E15. <PMid:28385134>

Duarte D.A.M., Ribeiro A.R., Vasconcelos A.M.M., Santos S.B., Silva J.V.D., Andrade P.L.A. \& Falcão L.S.P.C.A. 2009. Occurrence of Salmonella spp. in broiler chicken carcasses and their susceptibility to antimicrobial agents. Braz. J. Microbiol. 40(3):569-573. <http://dx.doi.org/10.1590/S1517$83822009000300020>$

Dutil L., Irwin R., Finley R., King N.G.L., Avery B., Boerlin P., Bourgault A.M., Cole L., Daignault D., Desruisseau A., Demczuk W., Hoang L., Horsman G.B., Ismail J., Jamieson F., Maki A., Pacagnella A. \& Pillai D. 2010. Ceftiofur resistance in Salmonella entericaserovar Heidelberg from chicken meat and humans, Canada. Emerg. Infect. Dis. 16(1):48-54. <http://dx.doi. org/10.3201/eid1601.090729><PMid:20031042>

Eaves D., Randall L., Gray D.T., Buckley A., Woodward M. J., White A.P. \& Piddock L.J.V. 2004. Prevalence of mutations within the quinolone resistancedetermining region of gyra, gyrb, parc, and pare and association with antibiotic resistance in quinolone-resistant Salmonella enterica. Antimicrob. Agents Chemother. 48(10):4012-4015. <http://dx.doi.org/10.1128/ AAC.48.10.4012-4015.2004> <PMid:15388468>

FDA 2012. Enteric Bacteria (NARMS): 2010 Executive Report. National Antimicrobial Resistance Monitoring System, Department of Health and Human Services, Food and Drug Administration, Rockville, MD.

Finley R.L., Collignon P., Larsson D.G.J., Mcewen S.A., Li, X.Z., Gaze W.H. \& Topp E. 2013. The scourge of antibiotic resistance: the important role of the environment. Clin. Infect. Dis. 57(5):704-710. <http://dx.doi.org/10.1093/ cid/cit355><PMid:23723195>

García-Fernández A., Gallina S., Owczarek S., Dionisi A.M., Benedetti I., Decastelli L. \& Luzzi I. 2015. Emergence of ciprofloxacin resistant Salmonella entericaserovarTyphi in Italy. Plos One 10(6):e0132065. <http://dx.doi. org/10.1371/journal.pone.0132065><PMid:26121266>

Gast R.K. 2013. Salmonella infections, p.677-736. In: Barnes H.J., Fadly A.M., Glisson J.R., Mc Dougald L.R. \& Sawyne D.E. (Eds), Diseases of Poultry. 13a ed. Iowa State Press, Iowa.

Górniak S.L. 2011. Sulfas, quinolonas e outros quimioterápicos, p.432-441. In Spinosa H.S., Górniak S.L. \& Bernardi M.M. (Eds), Farmacologia Aplicada à Medicina Veterinária. 5aㅡ ed. Editora Guanabara Koogan Ltda., Rio de Janeiro.

Gouvêa R.I., Santos F.F., Aquino M.H.C. \& Pereira V.L.A. 2015. Fluoroquinolones in industrial poultry production, bacterial resistance and food residues: a review. Revta Bras. Ciênc. Avícola 17(1):1-10. <http://dx.doi.org/10.1590/1516635x17011-10>

Ito N.M.K., Miyagi C.I., Lima E.A. \& Okabayashi S. 2005. Antimicrobianos: usos preventivos e curativos na avicultura. p.115-147. In: Palermo Neto J., Spinosa H.S. \& Górniak S.L. (Eds), Farmacologia Aplicada à Avicultura. Boas Práticas no Manejo de Medicamentos. Editora Rocca, São Paulo.

Kim K.Y., Hyun J., Kwak H.S. \& Woo G.J. 2011. Characterization of the quinolone resistance mechanism in foodborne Salmonella isolates with high nalidixic acid resistance. Int. J. Food Microbiol. 146(1):52-56. <http://dx.doi. org/10.1016/j.ijfoodmicro.2011.01.037><PMid:21354645>

Lai J., Wu C., Wu Ch., Qi J., Wang Y., Wang H., Liu Y. \& Shen J. 2014. Serotype distribution and antibiotic resistance of Salmonella in food-producing animals in Shandong province of China, 2009 and 2012. Int. J. Food Microbiol. 180:30-38. <http://dx.doi.org/10.1016/j.ijfoodmicro.2014.03.030> $<$ PMid:24786550>

Lin D., Chen K., Chan E.W.C. \& Chen S. 2015. Increasing prevalence of ciprofloxacin-resistant food-borne Salmonella strains harboring multiple PMQR elements but not target gene mutations. Scient. Rep. 5:14754 <http://dx.doi.org/10.1038/srep14754><PMid:26435519>

Mion L., Colla F., Cisco I., Webber B., Diedrich L., Pilotto F., Rodrigues L., Nascimento V. \& Santos L. 2014. Perfil de resistência a antimicrobianos por Salmonella Heidelberg isoladas de abatedouro avícola em 2005 e 2009. Acta Scient. Vet. 42(1):1-5.

Neves G.B., Stefani L.M., Pick E., Araujo D.N., Giuriatti J., Percio C. \& Brisola M.C 2016. Salmonella Heidelberg isolated from poultry shows a novel resistance profile. Acta Scient. Vet. 44(1):1-6. <http://dx.doi.org/10.22456/16799216.81294>

Pandini J.A., Pinto F.G.S., Muller J.M., Weber L.D. \& Moura A.C. 2015. Ocorrência e perfil de resistência antimicrobiana de sorotipos de Salmonella spp. isolados de aviários do Paraná, Brasil. Arqs Inst. Biológico, SãoPaulo, 82:1-6. <http://dx.doi.org/10.1590/1808-1657000352013>

Park H., Kim D., Yun N. \& Kim C. 2019. Identifying the mechanism underlying treatment failure for Salmonella Paratyphi A infection using next - generation sequencing - a case report. BMC Infect. Dis. 19(1):191. <http://dx.doi. org/10.1186/s12879-019-3821-x><PMid:30808284>

PHAC 2017. Annual Summary 2015. National Enteric Surveillance Program, Public Health Agency of Canada, Guelph. 
Rezende C., Fontana E.A., Freitas A.C.P. \& Colletes J.H.G. 2016. Avaliação de portadores assintomáticos de Salmonella em manipuladores de alimentos. Revta Bras. AnálisesClín. 48(3):32-35.

Robinson S. 2013. The big five: most common Salmonella strains in foodborne illness outbreaks. Food Safety News. Available at <http://www.foodsafetynews. com/2013/08/the-five-most-common-salmonella-strains/\#.UsbJ5dJDunI> Accessed on Nov. 19, 2018.

Rodrigues I.B.B.E., Ferreira K.F.S., Silva R.L., Machado S.C.A., Nascimento E.R., Rodrigues D.P., Aquino M.H.C. \& Pereira V.L.A. 2017. Amoxicillin/ clavulanc acid and cefotaxime resistance in Salmonella Minnesota and Salmonella Heidelberg from broiler chickens. Poult. Sci. J. 5(2):123-129. <http://dx.doi.org/10.22069/psj.2017.12886.1247>

Sinwat N., Poungseree J., Angkittitrakul S. \& Chuanchuen R. 2018. Mutations in QRDRs of DNA gyrase and topoisomerase IV genes in nalidixic acid and ciprofloxacin-resistant Salmonella enterica isolated from chicken meat, pork and humans. Thai J. Vet. Med. 48(1):79-84.

Thong K.L., Ngoi S.T., Chai L.C. \& Teh C.S.J. 2015. Quinolone resistance mechanisms among Salmonella enterica in Malaysia. Microbial Drug
Resistance 22(4):259-272. <http://dx.doi.org/10.1089/mdr.2015.0158> $<$ PMid:26683630>

WHO 2018. Antimicrobialresistance. World Health Organization, Genebra. Available at<http://www.who.int/news-room/fact-sheets/detail/ antimicrobial-resistance > Accessed on May 1, 2018.

Yan H., Wang H., Qin X., Liu B. \& Du J. 2011. Ultrasound-assisted dispersive liquid-liquid microextraction for determination of fluoroquinolones in pharmaceutical wastewater. J. Pharm. Biomed. Analysis 54(1):53-57. <http://dx.doi.org/10.1016/j.jpba.2010.08.007><PMid:20828967>

Yang B., Xi M., Cui S., Zhang X., Shen J., Sheng M., Qu D., Wang X. \& Meng J. 2012. Mutations in gyrase and topoisomerase genes associated with fluoroquinolone resistance in Salmonella serovars from retail meats. Food Res. Int. 45(2):935-939. <http://dx.doi.org/10.1016/j.foodres.2011.01.031>

Zankari E., Hasman H., Cosentino S., Vestergaard M., Rasmussen S., Lund O., Aarestrup F.M. \& Larsen M.V. 2012. Identification of acquired antimicrobial resistance genes. J. Antimicrob. Chemother. 67(11):2640-2644. <http://dx.doi.org/10.1093/jac/dks261><PMid:22782487> 